\title{
Identification and Characterization of a Novel Tobamovirus from Tropical Soda Apple in Florida
}

\author{
Scott Adkins, Ivanka Kamenova, and Erin N. Rosskopf, United States Department of Agriculture, Agricultural \\ Research Service, Fort Pierce, FL 34945; and Dennis J. Lewandowski, The Ohio State University, Department of \\ Plant Pathology, Columbus 43210
}

\begin{abstract}
Adkins, S., Kamenova, I., Rosskopf, E. N., and Lewandowski, D. J. 2007. Identification and characterization of a novel tobamovirus from tropical soda apple in Florida. Plant Dis. 91:287293.

Foliar symptoms suggestive of virus infection were recently observed on the noxious weed tropical soda apple (Solanum viarum) in Florida. An agent was mechanically transmitted to Nicotiana benthamiana, and virions were isolated from systemically infected leaves. Rodshaped particles $\sim 300 \mathrm{~nm}$ in length were observed in the partially purified preparations by electron microscopy. The host range determined by mechanical inoculation with purified virions included all tested plants in the Solanaceae (16 species including the important vegetable crops, pepper and tomato) and Chenopodiaceae ( 2 species) but excluded all tested plants in the Amaranthaceae, Apocynaceae, Brassicaceae, Caryophyllaceae, Cucurbitaceae, Fabaceae, Lamiaceae, Malvaceae, and Tropaeolaceae, including several common virus indicator hosts. Comparisons of the coat and movement protein nucleotide and deduced amino acid sequences of this putative tobamovirus with recognized members of this genus, indicate that it is a novel tobamovirus that shares the highest level of sequence identity with Pepper mild mottle virus followed by other members of the Solanaceae-infecting subgroup of tobamoviruses. The virus, for which the name Tropical soda apple mosaic virus (TSAMV) is proposed, was found to be widespread in tropical soda apple in peninsular Florida during an initial survey. TSAMV contamination of seed from infected tropical soda apple plants was found, suggesting that seed transmission may be important for TSAMV dissemination and epidemiology.
\end{abstract}

Tropical soda apple (Solanum viarum Dunal) is a solanaceous weed, armed with prickles on stems, leaves, petioles, and calyxes. It is native to Argentina, Brazil, Paraguay, and Uruguay (26) and was introduced in the 1980s into Florida, where it thrives as a perennial, particularly in the southern part of the state (11). It has spread rapidly throughout Florida, now occurring on more than 405,000 ha $(\sim 1$ million acres; 13). It is most commonly found in pastures but also occurs in citrus groves, sugarcane fields, and natural areas (23). Since the foliage is unpalatable to cattle, the weed has rapidly infested pastures (Fig. 1A), where the cattle ingest the aromatic fruits and perpetuate its spread (Fig. 1B). Based

Corresponding author: S. Adkins

E-mail: SAdkins@ushrl.ars.usda.gov

Current address of I. Kamenova: AgroBioInstitute, Sofia, Bulgaria.

* The $\boldsymbol{e}$-Xtra logo stands for "electronic extra" and indicates that Figure 1 appears in color in the online edition.

Accepted for publication 26 September 2006.

DOI: 10.1094/PDIS-91-3-0287

This article is in the public domain and not copyrightable. It may be freely reprinted with customary crediting of the source. The American Phytopathological Society, 2007. on 1993 data when tropical soda apple covered only 200,000 ha ( 494,000 acres) in Florida, losses to cattle ranchers in the state were estimated at $\$ 11$ million (22). Tropical soda apple was added to the Florida Noxious Weed List in 1994 and was declared a federal noxious weed in 1995 (19). It has now been reported from Alabama, Georgia, Louisiana, Mississippi, North Carolina, Pennsylvania, South Carolina, Tennessee, Texas, and Puerto Rico $(21,31,38)$, although many of these states have effective eradication programs underway. The occurrence of the weed in several of these states can be linked to the movement of cattle, bahiagrass seed, or composted manure from Florida (38). Based on ecological range studies, Patterson and colleagues (29) determined that temperature and photoperiod were not likely to limit the spread of this weed throughout the southern United States and into adjacent regions. Tropical soda apple has a measurable economic impact on bahiagrass productivity. In a study by Mullahey and colleagues (24), a high density of tropical soda apple plants reduced the number of grazing days by more than half when compared to a bahiagrass stand free of the weed.

Previous reports document viruses in several genera and families known to naturally infect tropical soda apple, including potyviruses (Potato virus $Y$ [PVY] and Tobacco etch virus [TEV]), a begomovirus
(Tomato mottle virus), a cucumovirus ( $\mathrm{Cu}$ cumber mosaic virus), and a tobamovirus (Tomato mosaic virus [ToMV]) $(17,18,37)$. Tropical soda apple has also been shown to be an experimental host for a variety of viruses (8). Another tobamovirus, Tobacco mild green mosaic virus (TMGMV), has recently been demonstrated to have potential as a biocontrol agent for tropical soda apple due to its induction of a rapid and lethal hypersensitive response following inoculation (30).

Foliar symptoms suggestive of virus infection were recently observed on tropical soda apple in Florida. An agent was mechanically transmitted to Nicotiana benthamiana from which a putative tobamovirus was isolated. In this paper, we present biological and molecular characterization of this tobamovirus, for which the name Tropical soda apple mosaic virus (TSAMV) is proposed. The host range of this virus, coupled with analysis of the nucleotide sequences of the coat protein (CP) and movement protein (MP) genes and the deduced amino acid sequences of the CP and MP, suggests that it is a novel member of the Solanaceae-infecting subgroup of the genus Tobamovirus.

\section{MATERIALS AND METHODS}

Virus sources and maintenance. Foliar mosaic symptoms suggestive of virus infection were initially observed on tropical soda apple plants growing in a cow pasture near Okeechobee, FL, in the fall of 2002. TSAMV, the putative tobamovirus characterized in this report, was originally transmitted from symptomatic tropical soda apple leaves to $N$. benthamiana by mechanical inoculation with an extract prepared by homogenization of leaves at a ratio of 1:10 (wt/vol) in $20 \mathrm{mM}$ sodium phosphate buffer ( $\mathrm{pH} 7.0$ ) containing $1 \%$ (wt/vol) Celite. Leaves of $N$. benthamiana exhibited a systemic mosaic, and were subsequently used to inoculate the local lesion host, $N$. tabacum cv. Xanthi nc (Table 1). A single local lesion was used to inoculate another $N$. benthamiana plant, and the virus was then increased and maintained in the greenhouse in this host by mechanical transmission. TMGMV and a Florida isolate of Pepper mild mottle virus (PMMoV; 2$)$ were maintained by the same method in N. tabacum cv. Xanthi.

Isolation and characterization of virions and double-stranded (ds) RNA. 
Virions were isolated from upper, uninoculated leaves of inoculated $N$. benthamiana (TSAMV) or N. tabacum cv. Xanthi (TMGMV and PMMoV) following a typical tobamovirus protocol (40). Extinction coefficients of $E_{260 \mathrm{~nm}}{ }^{0.1 \%}=3.18$ (TSAMV and PMMoV) and $E_{260} \mathrm{~nm}^{0.1 \%}=3.16$ (TMGMV) were used to estimate virus concentration spectrophotometrically $(39,40)$. TSAMV virion preparations were examined by electron microscopy on 300 mesh Formvar-coated copper grids after staining with $5 \%$ (wt/vol) uranyl acetate. Measurements of 101 virions were used to determine a mean particle length. Virions (TSAMV, TMGMV, and PMMoV) were analyzed by sodium dodecyl sulfatepolyacrylamide gel electrophoresis (SDSPAGE) on $15 \%$ SDS-PAGE gels and stained with Coomassie brilliant blue G250 according to established protocols (32).

DsRNA was extracted from 7-g samples of systemically infected $N$. benthamiana leaves following a protocol previously published (36) except that a single cycle of cellulose chromatography was used. DsRNA was analyzed by electrophoresis on native $5 \%$ polyacrylamide gels and detected by silver staining using a commercially available kit (Bio-Rad, Hercules, CA).

Host range determination. An experimental host range for TSAMV was determined by mechanically inoculating 33 species in 11 families with the virion preparation. All experimental hosts were grown from seed (except Adenium obesum and Solanum bahamense, which were propagated by cuttings from virus-free stock plants) and maintained in an airconditioned greenhouse under natural lighting with a daytime high temperature of $24^{\circ} \mathrm{C}$. All plants were mechanically inoculated with virions in the phosphate buffer indicated above at the three to five true leaf stage. Plants were evaluated weekly for symptoms. Local and systemic infection was confirmed at 2 weeks postinoculation by inoculation of $N$. glutinosa or $N$. tabacum cv. Xanthi nc with washed, inoculated or upper, uninoculated leaves, respectively, homogenized in phosphate buffer. One week later, inoculated leaves of $N$. glutinosa or $N$. tabacum cv. Xanthi nc were examined for necrotic local lesions.

Cloning and analysis of the CP and MP genes. Viral genomic RNA was extracted from virions according to previously described methods (25). First-strand cDNA was synthesized by Moloney murine leukemia virus reverse transcriptase (Promega, Madison, WI) at $50^{\circ} \mathrm{C}$ for 45 min with standard methods (32). One population of clones was prepared by priming first-strand cDNA synthesis with a previously described degenerate tobamovirus $3^{\prime}$ end primer (5'-TGGGCCSCWACC SGSGGT-3'; 1). This was followed by 30 cycles of polymerase chain reaction amplification with Taq polymerase (Promega) at $94^{\circ} \mathrm{C}$ for $30 \mathrm{~s}, 57^{\circ} \mathrm{C}$ for $1 \mathrm{~min}$, and $72^{\circ} \mathrm{C}$ for $1 \mathrm{~min} 30 \mathrm{~s}$ using the above primer and a second previously described degenerate tobamovirus primer (5'-GAYWCHMGD AAYAGRRYHATHGA-3') located within the CP gene (1). Products were ligated into pGEM-T (Promega). A second population of clones was prepared by priming firststrand cDNA synthesis with random hexamers. Second-strand cDNA was synthesized with the Klenow fragment of DNA Polymerase I. Products were phosphorylated with $\mathrm{T} 4$ polynucleotide kinase and ligated into the EcoRV site of pGEM5Zf (Promega). A third population of clones was prepared by priming firststrand cDNA synthesis with a primer $3^{\prime}$ of the MP gene (5'-GGTCAGCCCATACAG AAGCTA-3'). This was followed by 30 cycles of polymerase chain reaction amplification with $T a q$ polymerase as above using the above primer and a second primer (5'-ACCGCACCTCCTGGTTCG TTTG-3') based on PMMoV replicase gene sequences $5^{\prime}$ of the MP gene. Products were ligated into pGEM-T (Promega).

Selected clones were sequenced on an ABI3730XL automated sequencer at the USHRL DNA Sequencing Support Laboratory. Sequences were edited in VectorNTI
(InforMax, North Bethesda, MD) and subjected to BLAST searches (4). The only sequences producing significant alignments from BLAST queries were the CPs and MPs of recognized tobamoviruses. Overlapping clones were aligned manually and with ClustalX version 1.8 (33) to assemble the putative TSAMV CP and MP genes (GenBank accession nos. AY956381 and AY956382).

Multiple alignments of the CP and MP genes and deduced proteins of TSAMV and each recognized tobamovirus species were prepared using Clustal W version 1.82 (34) using Tobacco rattle virus as the outgroup. Percent nucleotide and amino acid identities were calculated using GeneDoc (27). Neighbor-joining trees were generated with PHYLIP version $3.6 a 3$ (12) programs DNADIST (CP gene and MP gene) or PROTDIST (CP and MP) and NEIGHBOR. The resulting trees were displayed in TreeView (28). The significance of the branching order was assessed by bootstrap resampling of 1,000 replicates using the SEQBOOT program of PHYLIP.

Production of polyclonal antiserum. A male New Zealand white rabbit was injected once, subcutaneously, with TSAMV virions $(100 \mu \mathrm{g})$ mixed with an equal volume of Complete Freund's Adjuvant at Cocalico Biologicals, Inc. (Reamstown, PA). Booster injections of virions $(50 \mu \mathrm{g})$ mixed with an equal volume of Incomplete Freund's Adjuvant were made subcutaneously and intramuscularly at 2, 3, 7, and 11 weeks after the initial injection. Production bleeds were started 1 week after the last booster injection. IgG was purified from the rabbit serum by ammonium sulfate precipitation as previously described (10) and stored with $0.5 \%$ (wt/vol) sodium azide at $4^{\circ} \mathrm{C}$.

Double-antibody sandwich-enzymelinked immunosorbent assay (DASELISA). Purified IgG at $1 \mathrm{mg} / \mathrm{ml}$ was conjugated with alkaline phosphatase (Roche Molecular Biochemicals, Indianapolis, IN) according to Avrameas (6). Conjugate was stored with $1 \%$ (wt/vol) bovine serum albumin and $0.5 \%$ (wt/vol)
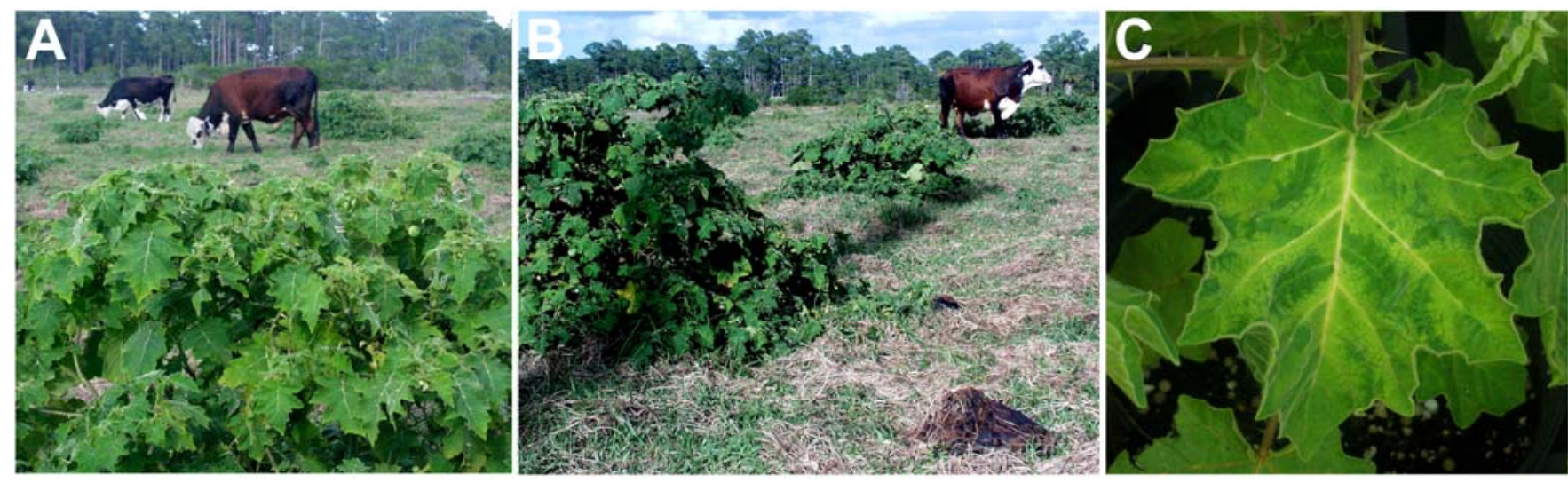

Fig. 1. Tropical soda apple is an invasive weed causing serious problems in pastures (A and $\mathbf{B}$ ) and is frequently moved by transport of cattle. C, Foliar mosaic induced on tropical soda apple following mechanical inoculation with Tropical soda apple mosaic virus. 
sodium azide at $4^{\circ} \mathrm{C}$. Preliminary DASELISA for TSAMV detection in infected tropical soda apple plants used a phosphate-buffered saline (PBS; $0.14 \mathrm{M} \mathrm{NaCl}$, $1 \mathrm{mM} \mathrm{KH} \mathrm{PO}_{4}, 8 \mathrm{mM} \mathrm{Na} \mathrm{HPO}_{4}, 2.5 \mathrm{mM}$ $\mathrm{KCl}$ [pH 7.4]) based buffer system previously described for the detection of a tobamovirus in hibiscus (1). High background signals were obtained from uninfected tropical soda apple plants (although not from other uninfected herbaceous plants), indicating that modification of the sample and/or conjugate dilution buffers was necessary. Although several tested additives effectively decreased the background from uninfected tropical soda apple plants, absorbance values with uninfected samples were lowest $\left(A_{405} \mathrm{~nm}=\right.$ 0.019 ) and absorbance values of infected samples were highest $\left(A_{405} \mathrm{~nm}=0.215\right)$ when the sample buffer was composed of PBS containing $0.5 \%$ (vol $/ \mathrm{vol}$ ) Tween 20 and $0.2 \%$ (wt/vol) sodium diethyldithiocarbamate (Na-DIECA) and the conjugate dilution buffer was composed of PBS containing $0.5 \%$ (vol/vol) Tween 20 and $1 \%$ (wt/vol) nonfat dry milk (NFDM). Cross- reaction of TSAMV IgG with partially purified preparations of Florida isolates of PMMoV and ToMV was initially observed but could also be eliminated by the addition of Na-DIECA and NFDM to the sample and conjugate dilution buffers, respectively.

A DAS-ELISA protocol was developed for detection of TSAMV directly from tropical soda apple leaves following published methods (10). Briefly, polystyrene microtiter plates were coated with TSAMV-specific IgG $(100 \mu \mathrm{l}$ of $5 \mu \mathrm{g} / \mathrm{ml}$ per well) diluted in $0.05 \mathrm{M}$ sodium carbonate buffer ( $\mathrm{pH}$ 9.6). Tissue was homogenized at a ratio of 1:10 (wt/vol) in the above sample buffer. Homogenate $(100 \mu \mathrm{l}$ per well) was added to the plate and incubated overnight at $4^{\circ} \mathrm{C}$. Plates were washed three times with PBS containing $0.5 \%$ (vol/vol) Tween 20 (PBST). Conjugated IgG (1:500 dilution in PBST containing $1 \%$ [wt/vol] NFDM, $100 \mu \mathrm{l}$ per well) was added to the plate and incubated $3 \mathrm{~h}$ at $37^{\circ} \mathrm{C}$. Plates were washed as above, $p$ nitrophenyl phosphate was added, and 405 $\mathrm{nm}$ absorbance $\left(A_{405} \mathrm{~nm}\right)$ readings were measured after a 1.5 to $2 \mathrm{~h}$ room temperature incubation. Controls of sample buffer only, uninfected leaves, and infected leaves were included in all assays. Four wells were used for each sample with the mean becoming the $A_{405 \mathrm{~nm}}$ reading for the sample. A threshold value for positive samples was set at three times the $A_{405 \mathrm{~nm}}$ reading of the uninfected control. The reliability of this DAS-ELISA protocol was demonstrated with assays of field samples, and seed and seedlings produced from mechanically inoculated tropical soda apple plants.

Survey for TSAMV. Tropical soda apple samples were collected in peninsular Florida and assayed by DAS-ELISA (described above) to develop an initial geographic distribution of TSAMV. Given previous reports of other tobamoviruses infecting tropical soda apple in Florida and beyond $(8,17,18,30,37)$, all samples were also analyzed with commercially available DAS-ELISA reagents specific for TMV strain U1 and with reagents that detect TMV and related tobamoviruses (including ToMV; Agdia, Elkhart, IN). Total RNA

Table 1. Experimental host range and symptoms of Tropical soda apple mosaic virus

\begin{tabular}{|c|c|c|c|}
\hline Family $^{\mathbf{a}}$ & Species & Common name & Symptoms $^{b}$ \\
\hline Amaranthaceae & Gomphrena globosa & Globe amaranth & $-1-$ \\
\hline Apocynaceae & Adenium obesum & Desert rose & $-1-$ \\
\hline \multirow[t]{4}{*}{ Brassicaceae } & Brassica oleracea cv. Brunswick & Cabbage & $-1-$ \\
\hline & Brassica oleracea cv. Copenhagen Market & Cabbage & $-1-$ \\
\hline & Brassica oleracea cv. Vates & Collards & $-1-$ \\
\hline & Brassica rapa cv. White Egg & Turnip & $-1-$ \\
\hline Caryophyllaceae & Dianthus chinensis cv. Spring Beauty & Dianthus & $-1-$ \\
\hline \multirow[t]{2}{*}{ Chenopodiaceae } & Chenopodium amaranticolor & Lambs quarters & CLL/- \\
\hline & Chenopodium quinoa & Lambs quarters & CLL/- \\
\hline \multirow[t]{4}{*}{ Cucurbitaceae } & Сиситis melo cv. Burpee Ambrosia Hybrid & Cantaloupe & $-1-$ \\
\hline & Cuситis melo cv. Burpee Sweet n' Early Hybrid & Cantaloupe & $-1-$ \\
\hline & Cucumis sativus cv. Burpee Straight 8 & Cucumber & $-1-$ \\
\hline & Cисиrbita pepo cv. Burpee zucchini hybrid & Squash & $-1-$ \\
\hline \multirow[t]{2}{*}{ Fabaceae } & Phaseolus vulgaris & Pinto bean & $-1-$ \\
\hline & Vigna unguiculata & Cow pea & $-1-$ \\
\hline Lamiaceae & Ocimum basilicum & Basil & $-1-$ \\
\hline \multirow[t]{2}{*}{ Malvaceae } & Abelmoschus esculentus cv. Clemson Spineless & Okra & $-1-$ \\
\hline & Gossypium hirsutum cv. DES 607 & Cotton & $-1-$ \\
\hline \multirow[t]{19}{*}{ Solanaceae } & Capsicum аппиит cv. Capistrano & Bell pepper & $\mathrm{Ch} / \mathrm{VN}, \mathrm{LD}$ \\
\hline & Capsicum аппиит cv. Enterprise & Bell pepper & $\mathrm{Ch} / \mathrm{PD}$ \\
\hline & Datura stramonium & Jimsonweed & NLL/NLL,VN \\
\hline & Lycopersicon esculentum cv. Bonnie Best & Tomato & $\mathrm{NS} / \mathrm{Ch}$ \\
\hline & Lycopersicon esculentum cv. Florida 47 & Tomato & NS/CLL,NLL \\
\hline & Nicotiana benthamiana & & NS/M \\
\hline & Nicotiana clevelandii & & $\mathrm{NS} / \mathrm{LD}$ \\
\hline & Nicotiana glutinosa & & NLL/- \\
\hline & Nicotiana megalosiphon & & NLL/- \\
\hline & Nicotiana meirsii & & NS/M \\
\hline & Nicotiana rustica & & NLL/NLL \\
\hline & Nicotiana sylvestris & & NLL/NS \\
\hline & Nicotiana tabacum cv. Xanthi & Tobacco & NS/NS \\
\hline & Nicotiana tabacum cv. Xanthi nc & Tobacco & NLL/- \\
\hline & Petunia $\times$ hybrida & Petunia & NLL/- \\
\hline & Physalis alkekengi & Chinese lantern & NS/FM \\
\hline & Solanum americanum & American black nightshade & NS/- \\
\hline & Solanum bahamense & Key West nightshade & NS/NS \\
\hline & Solanum viarum & Tropical soda apple & $\mathrm{M} / \mathrm{M}$ \\
\hline Tropaeolaceae & Tropaeolum majus & Nasturtium & $-1-$ \\
\hline
\end{tabular}

a Family and species names according to Brako et al. (7) and USDA, NRCS (35).

${ }^{\mathrm{b}}$ Symptoms on inoculated leaves and upper uninoculated leaves indicated to left and right of slash, respectively. $-=$ no infection, NS $=$ infected but no symptoms, $\mathrm{NLL}=$ necrotic local lesions, $\mathrm{CLL}=$ chlorotic local lesions, $\mathrm{Ch}=$ chlorosis, $\mathrm{PD}=$ plant death, $\mathrm{VN}=$ vein necrosis, $\mathrm{LD}=$ leaf deformation, $\mathrm{M}=$ mosaic, FM = faint mosaic. Local and systemic infection confirmed by inoculation of $N$. glutinosa or $N$. tabacum cv. Xanthi nc with washed, inoculated or upper, uninoculated leaves, respectively, homogenized in $20 \mathrm{mM}$ sodium phosphate buffer (pH 7.0) containing 1\% (wt/vol) Celite. 
was extracted from samples testing positive with the broad TMV DAS-ELISA (but not with the TMV U1 specific ELISA), subjected to reverse transcription-polymerase chain reaction (RT-PCR) using the above degenerate tobamovirus $\mathrm{CP}$ primers, and sequenced to determine the identity of the tobamovirus.

Contamination of seed by TSAMV. Tropical soda apple plants were mechanically inoculated at the three to five true leaf stage with TSAMV virions or buffer (mock) and maintained for seed production. Fruit from infected and mockinoculated plants were collected at maturity and allowed to dry. Seed were then collected from the dry fruit and tested individually for the presence of TSAMV, potentially due to either surface contamination of the seed or virus infection of the endosperm. An initial set of 28 seed from TSAMV-infected plants were tested and another 88 were tested in a subsequent experiment. Each single seed was soaked in $200 \mu \mathrm{l}$ sample buffer for $30 \mathrm{~min}$. These buffered samples were then loaded on microtiter plates precoated with TSAMV IgG and tested by DAS-ELISA. After three washes with distilled water, the seed were treated with a saturated solution of trisodium phosphate $(\sim 17.3 \% \mathrm{wt} / \mathrm{vol})$ for 30 min, and again washed with distilled water. Each seed was then individually ground in $200 \mu \mathrm{l}$ sample buffer using a mortar and pestle and tested for TSAMV by DASELISA.

Additional sets of 100 seed (from the same lots tested above) from infected and mock-inoculated plants were germinated, and seedlings were rated visually and tested by DAS-ELISA to determine whether seed transmission of TSAMV could occur. This was repeated with additional sets of 100 seed (again from the same lots tested above) following trisodium phosphate treatment of the seed.

\section{RESULTS}

Isolation and characterization of TSAMV. Virions were isolated from systemically infected $N$. benthamiana leaves and used to inoculate tropical soda apple plants, reproducing the systemic mosaic (Fig. 1C) observed in the original field sample. Electron microscopic examination of this partially purified preparation revealed rigid, rod-shaped particles (mean length of $298 \mathrm{~nm}$; Fig. 2A) that were typical of those described for tobamoviruses. TSAMV CP was analyzed by SDS-PAGE of virion preparations (Fig. 2B). TSAMV $\mathrm{CP}$ (Fig. 2B, lane 2) co-migrated with TMGMV (Fig. 2B, lane 1) and PMMoV (Fig. 2B, lane 3) CPs, indicating that the TSAMV CP is $\sim 17.5 \mathrm{kDa}$, although all three CPs migrated anomalously (apparently larger than they are) in comparison to markers (Fig. 2B, lane 4). No other proteins were observed, indicating that we had only isolated the putative tobamovirus from the infected tropical soda apple. A dsRNA that co-migrated with a Tobacco mosaic virus (TMV) dsRNA marker (data not shown) was isolated from infected $N$. benthamiana leaves, further suggesting that TSAMV was a tobamovirus.

Host range determination. An experimental host range for TSAMV was determined by mechanical inoculation of 33 species in 11 families (Table 1), including hosts reported for members of each of the four subgroups of the tobamoviruses and

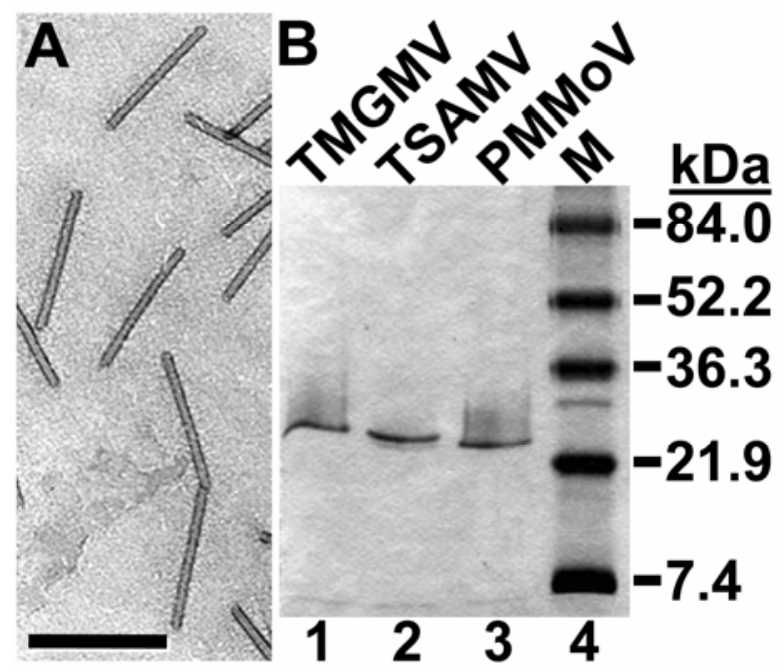

Fig. 2. Results of characterization of Tropical soda apple mosaic virus (TSAMV) by electron microscopy and coat protein (CP) analysis are consistent with it being a tobamovirus. A, TSAMV virion morphology is typical of recognized tobamoviruses. Virion preparation stained with 5\% uranyl acetate and analyzed by electron microscopy. Mean particle length of 101 measured virions was $298 \mathrm{~nm}$. Scale bar represents $300 \mathrm{~nm}$. B, TSAMV CP is similar in size to Tobacco mild green mosaic virus (TMGMV) and Pepper mild mottle virus (PMMoV) CPs. Aliquots of virion preparations (1,000 ng each) were analyzed by denaturing electrophoresis on a $15 \%$ sodium dodecyl sulfate-polyacrylamide gel and stained with Coomassie brilliant blue (lanes 1 to 3 ). The positions of prestained molecular weight markers (lane 4 ) are shown to the right of the gel (in $\mathrm{kDa}$ ).

unassigned members of the genus. No evidence of infection was detected in any of the tested Amaranthaceae, Apocynaceae, Brassicaceae, Caryophyllaceae, $\mathrm{Cu}$ curbitaceae, Fabaceae, Lamiaceae, Malvaceae, or Tropaeolaceae species, including several common virus indicator hosts. Chlorotic local lesions developed on inoculated leaves in both tested Chenopodiaceae species (Chenopodium quinoa and C. amaranticolor). All tested Solanaceae species were susceptible. Necrotic local lesions were observed on inoculated leaves of seven species (Datura stramonium, $N$. glutinosa, N. megalosiphon, $N$. rustica, $N$. sylvestris, N. tabacum cv. Xanthi nc, and Petunia $\times$ hybrida). TSAMV infection was localized to the inoculated leaves in $N$. glutinosa, N. megalosiphon, N. tabacum cv. Xanthi nc, Petunia $\times$ hybrida, and Solanum americanum. Symptomless systemic infections were detected in $N$. $t a-$ bacum cv. Xanthi and $S$. bahamense, similar to our previous observations with PMMoV and TMV, respectively $(2,3)$. Both tested cultivars of two solanaceous vegetable crops (pepper and tomato) showed obvious symptoms following inoculation with TSAMV. Pepper showed especially striking symptoms, with one cultivar exhibiting vein necrosis and leaf deformation and a second cultivar exhibiting plant death.

CP and MP sequence analysis. The nucleotide sequences of the putative $\mathrm{CP}$ and MP genes were determined from several overlapping clones. Nine independent clones of the TSAMV CP and MP genes were sequenced, and no sequence variation was observed between them. The CP gene consists of 483 nucleotides and encodes a protein of 160 amino acids with a predicted translation product of $17.7 \mathrm{kDa}$ (GenBank accession no. AY956381). The MP gene consists of 771 nucleotides and encodes a protein of 256 amino acids with a predicted translation product of $28.3 \mathrm{kDa}$ (GenBank accession no. AY956382). The only sequences producing significant alignments to the TSAMV $\mathrm{CP}$ and MP from BLASTN, BLASTX, and BLASTP queries were tobamovirus CPs and MPs, respectively, including many strains of some species. The most significant alignments (those yielding the highest percent identity) with TSAMV sequences were those of members of the Solanaceaeinfecting subgroup of tobamoviruses. The TSAMV CP nucleotide and amino acid sequences were aligned with the $\mathrm{CP}$ sequences of the 20 recognized tobamovirus species (16) for which $\mathrm{CP}$ sequence data are available, and the TSAMV MP nucleotide and amino acid sequences were aligned with the MP sequences of the 19 recognized tobamovirus species (16) for which MP sequence data are available. TSAMV sequences shared the most identity with PMMoV. TSAMV and PMMoV CPs share $80 \%$ nucleotide and $83 \%$ amino 
acid identity, respectively. Similarly, TSAMV and PMMoV MPs are 77 and $81 \%$ identical at the nucleotide and amino acid level, respectively. The TSAMV CP gene and deduced protein are only 42 to $68 \%$ and 33 to $75 \%$ identical at the nucleotide and amino acid level, respectively, to other tobamoviruses. The TSAMV MP gene and deduced protein are only 36 to $66 \%$ and 33 to $77 \%$ identical at the nucleotide and amino acid level, respectively, to other tobamoviruses.

The CP and MP amino acid alignments were used to infer neighbor-joining trees (Fig. 3) in which members of Solanaceae-, Brassicaceae-, Cucurbitaceae-, and Malvaceae-infecting subgroups of tobamoviruses clustered as previously demonstrated $(1,14,15,20)$. Trees based on nucleotide alignments of CP and MP genes had similar branching orders and bootstrap values throughout (data not shown). TSAMV always clustered with PMMoV and other members of the Solanaceae-infecting subgroup in our analyses, providing additional support for the biological and molecular data, suggesting that TSAMV is a novel tobamovirus in the Solanaceae-infecting subgroup.

Distribution of TSAMV. The additions of $0.2 \%$ (wt/vol) Na-DIECA to PBST for sample extraction and 1\% (wt/vol) NFDM to PBST for conjugate dilution were necessary to reduce high background absorbance observed from uninfected tropical soda apple plants and allowed development of a reliable DAS-ELISA protocol for field samples, seed, and seedlings. One hundred and ten tropical soda apple samples were collected from cow pastures and fallow land in 12 locations in seven Florida counties and analyzed for TSAMV and other Solanaceae-infecting tobamoviruses by DAS-ELISA. Fifteen percent of these samples, representing five locations in four counties adjacent to Lake Okeechobee, were positive for TSAMV (Fig. 4). Nine percent of these samples, representing four of these locations in two counties, were positive for ToMV. About one-third of the TSAMV-positive samples were also positive for ToMV.

Contamination of seed by TSAMV. In two experiments, 7/28 and 55/88 seed from TSAMV-infected plants were contaminated with TSAMV as determined by DAS-ELISA testing of individual seeds. A 30-min treatment with a saturated solution of trisodium phosphate eliminated seed positives, suggesting that TSAMV is only present on the seed surface and not in the endosperm. DAS-ELISA testing of seedlings grown from untreated, contaminated seeds showed that 1 to $16 \%$ of the seedlings became infected with TSAMV. Typical TSAMV symptoms were generally observed by the time the fifth or sixth true leaf emerged. Trisodium phosphate treatment of contaminated seed eliminated infected seedlings, further suggesting only

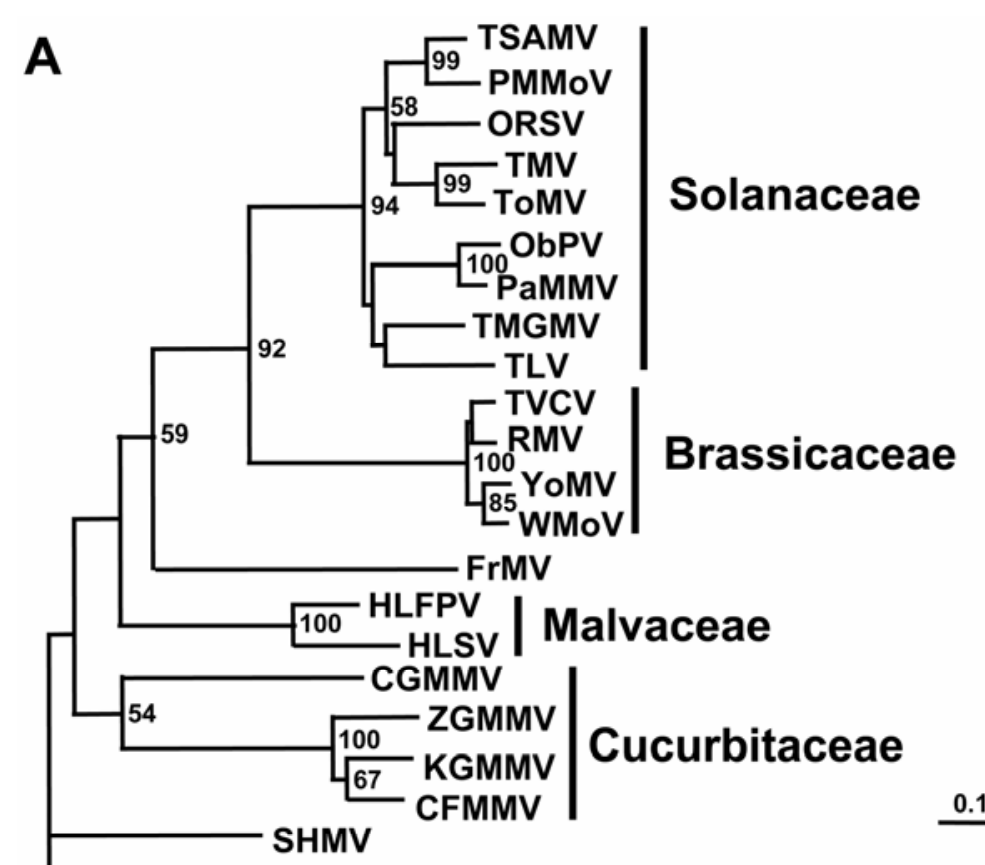

TRV

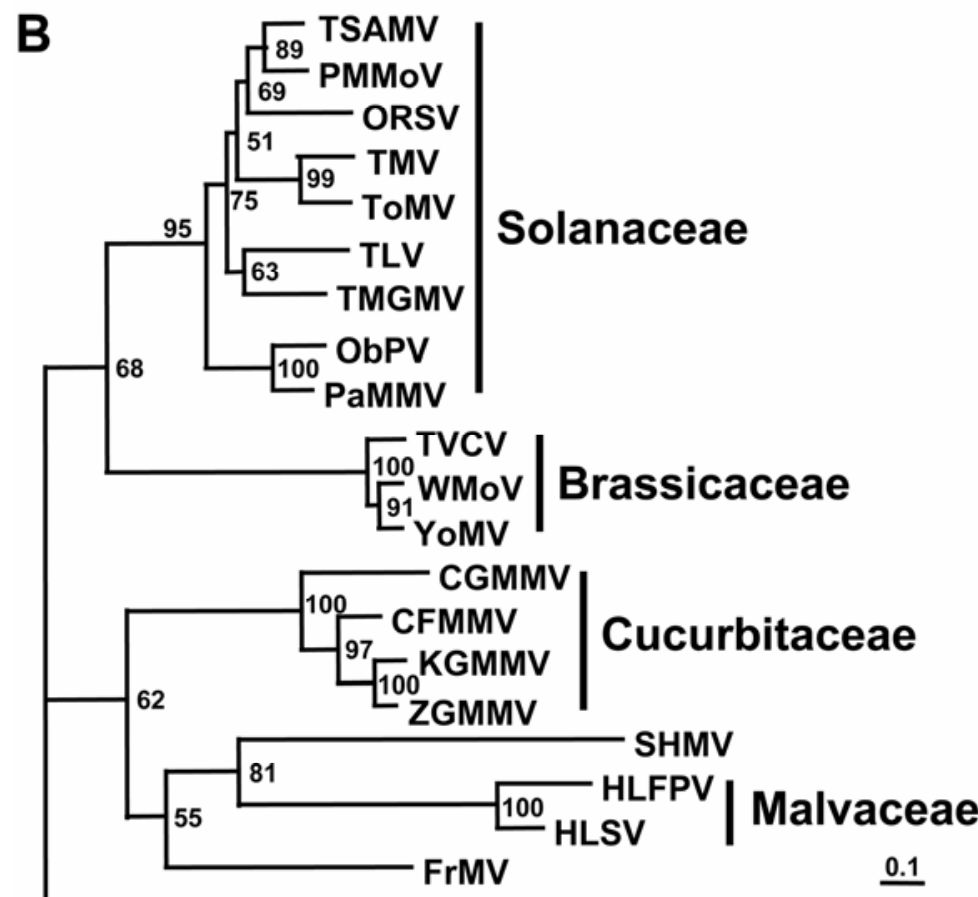

TRV

Fig. 3. Comparison of coat protein (CP, A) and movement protein (MP, B) amino acid sequences of Tropical soda apple mosaic virus (TSAMV) and the recognized species in the genus Tobamovirus. Neighbor-joining trees were inferred using Phylip version 3.6b (12) with Tobacco rattle virus (TRV, NC_003811 and NC_003805) as an outgroup. Significance of the branching order was assessed by bootstrap resampling of 1,000 replicates, and values $\geq 50 \%$ are indicated. Viruses included (listed with abbreviation and GenBank accession no. for nucleotide sequence) are: Cucumber fruit mottle mosaic virus (CFMMV, NC_002633), Cucumber green mottle mosaic virus SH strain (CGMMV, NC_001801), Frangipani mosaic virus (FrMV, AF165884), Hibiscus latent Fort Pierce virus (HLFPV, AY250831 and AY596456), Hibiscus latent Singapore virus (HLSV, AF395898 and AF395899), Kyuri green mottle mosaic virus Yodo strain (KGMMV, AB015145), Obuda pepper virus (ObPV, NC_003852), Odontoglossum ringspot virus (ORSV, U89894), Paprika mild mottle virus (PaMMV, NC_004106), Pepper mild mottle virus S strain (PMMoV, NC_003630), Ribgrass mosaic virus (RMV, U69271), Sunn-hemp mosaic virus (SHMV, J02413), Tobacco latent virus (TLV, AY137775), Tobacco mild green mosaic virus (TMGMV, NC_001556), Tobacco mosaic virus (TMV, NC_001367), Tomato mosaic virus (ToMV, NC_002692), Tropical soda apple mosaic virus (TSAMV, AY956381 and AY956382), Turnip veinclearing virus (TVCV, NC_001873), Wasabi mottle virus (WMoV, NC_003355), Youcai mosaic virus (YoMV, formerly referred to as Chinese or Oilseed rape mosaic virus, NC_004422), and Zucchini green mottle mosaic virus (ZGMMV, NC_003878). Solanaceae-, Brassicaceae-, Malvaceae-, and Cucurbitaceae-infecting subgroups are indicated. This is an unrooted tree. 
external contamination. No TSAMV was detected by DAS-ELISA in seed from mock-inoculated plants or seedlings grown from them, nor were any symptoms observed on these seedlings.

\section{DISCUSSION}

TSAMV appears to be a novel tobamovirus based on several criteria. Isolated virions had a morphology consistent with those of other members of the genus Tobamovirus (Fig. 2A), and were subsequently used to infect tropical soda apple, resulting in the originally observed symptoms (Fig. 1C). The TSAMV CP is similar in size to those of TMGMV and PMMoV (Fig. 2B). The dsRNA profile was also consistent with those of the tobamoviruses. CPs and MPs of recognized tobamoviruses were the only sequences producing significant alignments from BLAST queries with the TSAMV CP and MP sequences, respectively.

Grouping tobamoviruses by host range or sequence produces similar results $(1,5,14,15,20,41)$. We have aligned the TSAMV CP and MP with sequences of the recognized tobamovirus species (16) and used these alignments to infer neighborjoining trees (Fig. 3). The TSAMV CP and MP always clustered with members of the Solanaceae-infecting subgroup, consistent with its host range (Table 1). The TSAMV $\mathrm{CP}$ gene is most similar to PMMoV (80\% nucleotide identity), yet this is well below the currently accepted $90 \%$ cutoff for demarcating tobamovirus species (16). Thus, our sequence comparisons of the TSAMV $\mathrm{CP}$ and MP indicate sufficient sequence differences to warrant consideration of TSAMV as a distinct tobamovirus species.

Detection and characterization of TSAMV increase the importance of tropical soda apple as a virus reservoir and expand the genus Tobamovirus. Our initial virus surveys have detected TSAMV, often in mixed infections with ToMV, in tropical soda apple in the Florida peninsula (Fig.

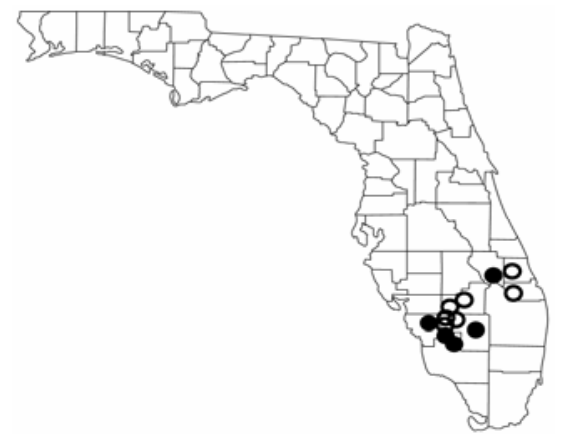

Fig. 4. Distribution of Tropical soda apple mosaic virus in peninsular Florida. Map shows Florida counties with 12 locations (indicated by circles) from which 110 tropical soda apple plants were sampled. Filled circles indicate the presence of at least one infected plant as determined by double antibody sandwich enzymelinked immunosorbent assay.
4). In addition, we detected three potyviruses (PVY, TEV, and Bidens mottle virus) in collaboration with Carlye Baker (FDACS-DPI, data not shown), and recently tropical soda apple was shown to be a host for root-knot nematode (9). Due to TSAMV primarily infecting hosts in the Solanaceae, which includes several important vegetable crops like pepper and tomato, tropical soda apple takes on added importance as a virus reservoir. This is especially true in south Florida where vegetable and cattle production are often adjacent, and in some cases land is rotated between vegetables and cattle. This is particularly important because of the perennial nature of the weed, which allows for its presence long after the completion of a crop. In addition, the ability of tropical soda apple to regenerate from roots (22) increases the risk of infection in a subsequent crop.

Given the widespread nature of tropical soda apple and TSAMV, seed transmission could be important in TSAMV dissemination and epidemiology. Our results show that seed from TSAMV-infected plants are contaminated with virus and can lead to infected seedlings. These results are in contrast to those of McGovern and colleagues (18) with ToMV, where no seed transmission was reported. In our experiments, trisodium phosphate treatment of contaminated seed effectively eliminated detectable TSAMV contamination of seed and also infected seedlings, suggesting only external contamination with TSAMV. Finally, we observed that tropical soda apple grown from seed collected from TSAMV-infected plants were consistently smaller than those plants grown from seed collected from mock-inoculated plants. This apparent physiological effect of virus infection is being explored further.

\section{ACKNOWLEDGMENTS}

We thank Carrie Vanderspool, Debra Stillman, and Shannon Clark for their excellent technical assistance, Diann Achor for electron microscopy, and Phil Stansly and Gene McAvoy for helping us collect field samples.

\section{LITERATURE CITED}

1. Adkins, S., Kamenova, I., Achor, D., and Lewandowski, D. J. 2003. Biological and molecular characterization of a novel tobamovirus with a unique host range. Plant Dis. 87:11901196.

2. Adkins, S., Lamb, E. M., Roberts, P. D., Gooch, M. D., Breman, L., and Shuler, K. D. 2001. Identification of Pepper mild mottle virus in commercial bell pepper in Florida. Plant Dis. 85:679.

3. Adkins, S., and Rosskopf, E. N. 2002. Key West nightshade, a new experimental host for plant viruses. Plant Dis. 86:1310-1314.

4. Altschul, S. F., Madden, T. L., Schäffer, A. A., Zhang, J., Zhang, Z., Miller, W., and Lipman, D. J. 1997. Gapped BLAST and PSI-BLAST: A new generation of protein database search programs. Nucleic Acids Res. 25:3389-3402.

5. Antignus, Y., Wang, Y., Pearlsman, M., Lachman, O., Lavi, N., and Gal-On, A. 2001. Biological and molecular characterization of a new cucurbit-infecting tobamovirus. Phytopa- thology 91:565-571.

6. Avrameas, S. 1969. Coupling of enzyme to proteins with glutaraldehyde. Immunochemistry 6:43-52.

7. Brako, L., Rossman, A. Y., and Farr, D. F. 1995. Scientific and Common Names of 7,000 Vascular Plants in the United States. American Phytopathological Society, St. Paul, MN

8. Chagas, C. M., Grill, M., Noronha, A. B., and Vicente, M. 1978. Solanaceas silvestres como hospedeiras experimentais de virus. I. Solanum ciliatum Lam., S. palinacanthum Dun. e $S$. viarum Dun. Arq. Inst. Biol. São Paulo 59:43-48.

9. Church, G., and Rosskopf, E. 2005. First report of the root-knot nematode Meloidogyne arenaria on tropical soda apple (Solanum viarum) in Florida. Plant Dis. 89:527.

10. Clark, M. F., and Adams, A. N. 1977. Characterization of the microplate method of enzymelinked immunosorbent assay for the detection of plant viruses. J. Gen. Virol. 34:475-483.

11. Coile, N. C. 1993. Tropical Soda Apple, Solanum viarum Dunal: The Plant from Hell. Florida Department of Agriculture and Consumer Services, Division of Plant Industry. Bot. Circ. 27

12. Felsenstein, J. 1989. PHYLIP - Phylogeny Inference Package. Version 3.2. Cladistics 5:64-166.

13. Ferrell, J. A., and Mullahey, J. J. 2005. Tropical soda apple (Solanum viarum Dunal) in Florida. Florida Cooperative Extension Service, Institute of Food and Agricultural Sciences, University of Florida, Gainesville. Publ. \#SS-AGR-50.

14. Gibbs, A. 1999. Evolution and origins of tobamoviruses. Phil. Trans. R. Soc. Lond. B 354:593-602.

15. Lartey, R. T., Voss, T. C., and Melcher, U. 1996. Tobamovirus evolution: Gene overlaps, recombination, and taxonomic implications. Mol. Biol. Evol. 13:1327-1338.

16. Lewandowski, D. J. 2005. Virus Taxonomy Classification and Nomenclature of Viruses, 8th Report of the ICTV. C. M. Fauquet, M. A Mayo, J. Maniloff, U. Desselberger, and L. A. Ball, eds. Elsevier Academic Press, San Diego. pp. 1009-1014.

17. McGovern, R. J., Polston, J. E., Danyluk, G. M., Hiebert, E., Abouzid, A. M., and Stansly, P. A. 1994. Identification of a natural weed host of tomato mottle geminivirus in Florida. Plant Dis. 78:1102-1106.

18. McGovern, R. J., Polston, J. E., and Mullahey, J. J. 1994. Solanum viarum: Weed reservoir of plant viruses in Florida. Int. J. Pest Manag. 40:270-273.

19. Medal, J. C., Coile, N. C., Gandolfo, D., and Cuda, J. P. 2002. Status of biological control of tropical soda apple, Solanum viarum, in Florida. Florida Department of Agriculture and Consumer Services, Division of Plant Industry. Bot. Circ. 36

20. Min, B. E., Chung, B. N., Kim, M. J., Ha, J. H., Lee, B. Y., and Ryu, K. H. 2006. Cactus mild mottle virus is a new cactus-infecting tobamovirus. Arch. Virol. 151:13-21

21. Mullahey, J. J. 1996. Tropical soda apple (Solanum viarum Dunal), a biological pollutant threatening Florida. Castanea 61:255-260.

22. Mullahey, J. J., and Cornell, J. 1994. Biology of tropical soda apple (Solanum viarum), an introduced weed in Florida. Weed Technol. 8:465-469.

23. Mullahey, J., Nee, M., Wunderlin, R. P., and Delaney, K. R. 1993. Tropical soda apple (Solanum viarum): A new weed threat in subtropical regions. Weed Technol. 7:783-786.

24. Mullahey, J. J., Roka, F., Fanning, M. D., and Akanda, R. 1999. Effect of tropical soda apple density on bahiagrass production. Proc. Southern Weed Sci. Soc. 52:76

25. Navas-Castillo, J., Albiach-Marti, M. R., Gowda, S., Hilf, M. E., Garnsey, S. M., and 
Dawson, W. O. 1997. Kinetics of accumulation of citrus tristeza virus RNAs. Virology 228:9297.

26. Nee, M. 1991. Solanaceae III: Taxonomy, Chemistry, Evolution. J. G. Hawkes, R. N. Lester, M. Nee, and N. Estrada, eds. Royal Botanical Gardens, Kew, Surrey, UK. pp. 258266.

27. Nicholas, K. B., and Nicholas, H. B., Jr. 1997. GeneDoc: A tool for editing and annotating multiple sequence alignments. Pittsburgh Supercomputing Center, Pittsburgh, PA.

28. Page, R. D. M. 1996. TREEVIEW: An application to display phylogenetic trees on personal computers. Computer Applic. Biosci. 12:357-358.

29. Patterson, D. T. M., McGowan, M., Mullahey, J. J., and Westbrooks, R. G. 1997. Effects of temperature and photoperiod on tropical soda apple (Solanum viarum Dunal) and its potential range in the U.S. Weed Sci. 43:504-513.

30. Petersen, M. S., Charudattan, R., Hiebert, E., and Zettler, F. W. 2001. Tobacco mild green mosaic virus (TMGMV) induces a lethal hy- persensitive response tropical soda apple (Solanum viarum Dunal). (Abstr.) Phytopathology 91:S71.

31. Reed, M., and Ketchersid, K. 2004. Solanum viarum (Solanaceae)-tropical soda appleconfirmed from Texas. Sida 21:1171-1174.

32. Sambrook, J., and Russell, D. W. 2001. Molecular Cloning: A Laboratory Manual, 3rd ed. Cold Spring Harbor Laboratory, Cold Spring Harbor, NY.

33. Thompson, J. D., Gibson, T. J., Plewniak, F., Jeanmougin, F., and Higgins, D. G. 1997. The ClustalX Windows interface: Flexible strategies for multiple sequence alignment aided by quality analysis tools. Nucleic Acids Res. 24:4876-4882.

34. Thompson, J. D., Higgins, D. G., and Gibson, T. J. 1994. CLUSTAL W: Improving the sensitivity of progressive multiple sequence alignment through sequence weighting, positionspecific gap penalties and weight matrix choice. Nucleic Acids Res. 22:4673-4680.

35. U.S. Dep. Agric., NRCS. 2006. The PLANTS Database. National Plant Data Center, Baton
Rouge, LA. Published online.

36. Valverde, R. A., Nameth, S. T., and Jordan, R. L. 1990. Analysis of double-stranded RNA fo plant virus diagnosis. Plant Dis. 74:255-258.

37. Vicente, M., Chagas, C. M., and July, J. R. 1979. Three wild Solanaceae plants as natural hosts for a potyvirus. Fitopathol. Bras. 4:7376.

38. Westbrooks, R. 1998. Invasive plants, changing the landscape of America: Fact book. Federal Interagency Committee for the Management of Noxious and Exotic Weeds (FICMNEW), Washington, DC.

39. Wetter, C. 1989. Tobacco mild green mosaic virus. CMI/AAB Descriptions of Plant Viruses No. 351.

40. Wetter, C., and Conti, M. 1988. Pepper mild mottle virus. CMI/AAB Descriptions of Plant Viruses No. 330.

41. Yoon, J. Y., Min, B. Y., Choi, J. K., and Ryu, K. H. 2002. Genome structure and production of biologically active in vitro transcripts of cucurbit-infecting Zucchini green mottle mosaic virus. Phytopathology 92:156-163. 